\title{
THE DEFINITION AND IMPORTANCE OF LOCAL GOVERNANCE
}

Aurora Ndreu'

European University of Tirana, Tirana, Albania

\section{ABSTRACT}

There is no precise and universal definition about what is administrative law, but rationally it can be determined that covers the organization, functions, duties and responsibilities of public authorities of all kinds who take part in the administration, relations between them and citizens or between them and non-governmental bodies. It defines legal methods for controlling public administration as well as the rights and duties of officials. We must say that administrative law theory over time has slipped into a legitimate model that underlies the political control of the administrative policy. It must be admitted that the role played by political decision making in administrative ones has greatly increased, viewed from the perspective of a very questionable democratic theory. According to legal positivism or Hart defined by Kant, the most important moral principles between standards are identified as governing laws. So we first have the social fact, and this fact can be then a law. Thus was born the administrative law as a socia fact. So a rule, can be turned into a law, welcomed by all the society. From the administrative law it was defined the local governance definition. The existence of modern already legal positivism, which enables morality or political morality to return to positive law through several methods become an inclusive part of a set of naturally beliefs.

\section{UDC \& KEYWORDS}

UDC: 342 '35 LOCAL GOVERNANCE CHARACTERISTICS IMPORTANCE DEFINITION

\section{INTRODUCTION}

Albania is a unitary state since its creation. The jurisprudence recognizes the unitary and federal states. The federal states have typically two-level system of governance, governance in center / federal as first level and in the federa state government as second-tier governance. Such countries are Germany or Switzerland. The unitary states where our country belongs have a central government which determines the general policy of development of the country. The simplest definition of local government is that this kind of governance is an institutional and legal organization such that ensures that people within a given territory act collectively to ensure their welfare.

Local governance need to happen when people live in a community and have sufficiently close interaction (Crawford, $1999 ; 15$ ) and to solve their problems they must work together as a group in order to achieve the results they want. Two basic elements that can be distinguished in this government are: management of public services and representation of citizens. These elements are not only distinctive element of local government but also serve as an indicator of the effectiveness of such a government. The problem lies in determining which of these elements is more important or more developed? This has changed from time to time or from place to place. Nowadays I am convinced 'n.aurora@yahoo.com that we can not talk about the element of representation as this element has been implemented already and fallen ground. Today in our studies we can talk about times where democratic governance elements are the basis for the foundation of a state. At this point the problem remains to determine how the function of providing services was due to efficiency.

We should not forget that the local institutions are there not only to provide various public services to citizens, but also to represent in the best way possible the will of the people (Tindal, 1977: 3). Finally, the question of why there should be local government we can respond because of the simple reason of providing various public services to citizens and ensure the representation of the will of the people.

In relation to the fact of being an instrument of democracy about local governance, there are opponents who see it as something abstract because you can associate this with low participation of citizens in local elections or with the lack of competition between governing platforms, for now seen as political party competition rather than governing platforms, up to a point, this approach can not be underestimated. Once, such an approach could exclude politics or political dependence of local government and would be of great interest and will bring more effectiveness. The system where many European countries are turning more and more, enabling the delivery of many public services by private, through privatization or concession, can achieve something like that. A system where local governments to divest from political influence but simply be a steward of public service delivery.

A local unit is a legal entity that provides public services to its people within the territory where it exercises jurisdiction, but it is also a democratic institution which from the decision making point of view, is governed by a council with representatives elected by the people who are accountable to their constituents (Tindal, 1977; 2).

In order this kind of government can function, the literature suggests that several conditions must be met:

- There should be a clear division of responsibilities between local and central government.

- There should be a clear and easily identifiable division in borders. Each citizen should know which local unit belongs and to exercise his right of choice in this unit.

But we can not have a clear-cut division since today are well recognized many forms of collaboration between different local government units, which happens to be offered one or several services to two or more units. Consequently, such separation takes secondary importance given the purpose sought to be achieved.

- Each local unit needs a financial, geographic and demographic base where it can exercise the rights and take responsibilities.

This means that the unit must be able to administer the taxes collected and provide services to citizens within 
the financial capacity created by these taxes. Why is it necessary to do so? As we know one way of controlling over an institution or unit is the financial control. If you do the opposite analysis, independence and autonomy of an institution is greater when it is held by its funds than when funds are provided by other levels of government. This means that if the unit is not effective in meeting the needs within its incomes, then it will have to seek additional funding from other levels, and this will lead to lower and easily vulnerable autonomy.

The local unit should be well organized from the institutional and administrative reforms in order to have a clear division of responsibilities between the persons elected and appointed.

This takes us to a very important element that is accountability. In an institution where there is democracy, there must be accountability.

- The relationship between directly elected officials, part of decision making body of the council and appointed officials should be productive and cooperative in order to perform the functions of the services offered to citizens (Tindal, 1977: 2-4).

According to the definition given by the OECD (Organization for Economic Cooperation and Development), the local government is based on fiscal governance, legislative and executive authority over an area corresponding to the territorial limit and a certain group of people.

Given the above definition we see that this kind of governance is associated with two important elements, decentralization and local autonomy. The question arises what is decentralization? Decentralization is the provision or distribution of certain functions, within administrative, political or economic attributes, from central government to local government. The latter is independent of the center within the territory under its authority (Faguet, 2005; 6).

The European Charter on Local Autonomy defines local self-government as the right and ability of local authorities within the limits set by law, to manage public services in the interest of the local population where they carry responsibilities.

During his long experience and trip in America, De Tocqueville, concluded that as much as American citizens participating in political events or not, whether civil societies, the more democratic values had a chance. So a wider participation constituted an essential element of the American democratic practices (De Tocqueville, 1966).

This means that the more closely the citizens' participation in management of local affairs in a certain local unit, the more likely to democratic governance, autonomy or selfgovernance is this unit. Here we return once again to the essential element of self-governance, namely the representation and participation of citizens.

Because the process of governance is seen as a relationship between civil society and government, thereby determining the government's actions (Wilson, 2000; 51-63), if the government has no adequate capacity to act, then the process of governance remains something empty, meaningless.

When it comes to local government, this concept takes a broader sense. This is because the capacity and the development of local governance affect the development or not of a state. In this result affects several factors, such as human resource capacity of local government units, the relationship with the central government or autonomy in decision making by the latter. Given that above we talked about the relationship between the government and civil society, in the case of local governance this relationship goes in one direction, then the local government provides services to the citizens, while the latter have limited access to influence local politics in most cases, so the governance link is no longer effective (Wilson, 2000; 57).

Consequently, to better meet the needs of citizens, is required a decentralization of the main functions, delegating to those closest to them. But decentralization, as far as is necessary and indispensable and is the basis for a selfgovernance, also constitutes a risk for countries in development, where factors such as lack of human resources, financial and institutional one, may bring negative consequences for local units. Here we can make an analogy with the process of integration into the European Union by the aspirant countries. Besides the given detailed conditions to be a member, a crucial element is the ability or capacity of the aspirant state to be absorb by the organisation. This means that the EU is open for membership if it meets the requirements set, but is it the country ready for such a step, as this would require a strict regime of tougher policies to integrate. The same thing happens with the decentralization process, the central government actually provides more functionality and local units responsibility, but the problem is how the latter are able to absorb and develop this service?

Although we proclaim the importance of self-government organs and its autonomy, we must not forget that this government itself is inextricably linked with other levels of government through constitutional provisions, financial relations or shared responsibilities in the implementation of various projects that can take together.

Between decentralization, local and central government there is a complex relationship, because on the one hand decentralization improves the operations of local governments, but the latter operates through a number of intergovernmental relationships that may limit their actions. As regard the decentralization can not be understood without fiscal decentralization. But in practice the central government don't think anymore of a of full fiscal decentralization, as the national tax collector capacity is many times more efficient than that of local government. A complete decentralization will give rise to differentiation between local units, where those with higher incomes will further enrich themselves and those with low incomes will become poorer.

\section{Definitions related to local governance}

What are the accepted definitions of terminology in local government? As it is described by researchers or academics?

Local government can be described as some government bodies elected by the people that have administrative, legislative and executive functions on the territories under their jurisdiction. It is defined as an authority that decides or determines certain measures within a given territory.

If we will do a literally analysis of the word or terminology, it means governance or management of local affairs by the people part of that community. Here comes the important principle of subsidiarity, according to which local needs can be better met and fulfilled by people close to them, then the central government

According to the researcher Clarke (Aijaz, 2007) local government is part of the government of a country which deals mainly with problems or issues related to a given population within a given territory. This is done basically on 
the responsibilities of a country that parliament decides to delegate by the laws to local governance. In this definition we find two important elements of local government, that of the existence of directly elected local bodies and local finances, which constitute common denominators of each local government.

While Lockard (Lockard, 1963) thinks that the local government can be defined as a public organization, authorized to establish and administer public policies within a given territory, the latter is a subdivision of the central government. In fact the organization of local government is public organization, changing from private organizations, they are aimed at the general interest of citizens.

Local Government according to Hasluck (Hasluck, 2010) is the sphere of government where local authorities are allowed by law to issue acts or decisions to adjust the way of governance. In his book "Elements of Politics", Sidgwick (Sidgwick, 2014) considers local government as government of some suborgans that have special powers to issue regulations or rules within the area which they manage. So Sidgwick connects this government with its legislative character.

Stones in his definition (Stones, 1968) defines local government as part of the governance of a country, but that deals with problems or issues of population within certain territory or location. According to him, this kind of government does the so-called "housework" so that living in these areas to be affordable for its residents. It achieves this by keeping the roads clean, children's education, residential housing construction etc.

In a socio-developmental definition, given by L. Godwin (Godwin, 2014) on local governance, he defines this kind of government as management of their affairs by the people of the locality where they are. Although short, this definition socially finds place.

According to Humes and Martin (Humes \& Martin, 1961) local government should have the following features:

- have a certain population,

- a specific surface area,

- the capacity to sign contracts or to enter into relationships with third parties, i.e. the legal status and authority,

- have a continuous organization and,

- to realize the financial function therefore have the capacity to collect taxes and determine its budget

Hampton in his book "The local government and urban policy" states that local authorities have boundaries defined geographically, are organs highly functional, directly elected, but on the other hand have disabilities related to the determination of local taxes, this comes depending on the determination of the margin from the central government (Hampton, 1991).

But when Keating compares urban policies in different countries as America, Canada, France or Britain (Keating, 1991) he sees local units as individual associations or organizations who decided to govern its own works, by defining the scope and limits of the powers.

For Wilson and Game (Wilson and Game, 2006) local governance is a multi-functional and geographic organization determined on pursuing social objectives, economic or political ones, through funds given from above or those provided by its revenues, which regulates and monitors all areas of public services within the local community.

If we consider all the definitions given above, it appears that the common denominator of all these is at first the central and local government relationship on the one hand and local government relationship with the local community on the other.

\section{The main characteristics of local government}

From the analysis of all the definitions made to local government by different authors, emerge the following main features:

- first, this government has statutory status, therefore it is defined, recognized and functions on the basis of the laws of a country (in our country, in Albania, local government bodies are constitutional bodies),

- secondly, these bodies have the right to decide about their own local taxes on the territory where extend jurisdiction,

- thirdly, they are characterized by the right of local community participation in decision making process or management of local affairs,

- fourth, it is known the capacity to act independently from central government bodies, within the limits set by law, through the decentralization process or the principle of local autonomy,

- fifth, these bodies serve the general interest of the citizens, i.e. common interest.

Analysis of all the definitions given above shows that local government is a combination of several elements, such as the existence of a local authority regulated by law, the local population and a defined territory, autonomy limited by the central government, separation of local and non local functions.

While as its integral characteristics we can mention:

- There has a certain local area. Each local government unit has a clearly defined area where it operates. This area may be a city, village, region, etc., depending on the territorial organization of the state itself. Surface and its limits are imposed by the central government or parliament by special laws.

- Has the local authority. Management or governance of a certain locality is made by a body composed of persons directly elected by the people of that area. This representative body is responsible for the administration of local affairs in that area.

- Provides public services for residents of the area within its jurisdiction, which is the main goal of this government.

- Local finances: In order to provide services and perform functions effectively, it is imperative that the local unit has its own finances. Because the services it provides to citizens should be financially covered. These finances can be obtained from local taxes but also from state subsidies.

- Local autonomy: This means that the local government has the right to establish and operate in the activities and functions that are recognized by law. It also includes the legal right of local residents to choose their representatives that will govern the territory under the set laws. It should be noted that autonomy does not mean sovereignty over these bodies, as belonging and legally depending on state structures. 
- Local Participation: The success or failure of the development plans of the territory it relates to how much active participation of the local people is there. Through this government it is sought greater participation of people who are given the opportunity to participate in the decision making process. Its a condition that, if a goal to be achieved, then the participation of the public should be necessarily.

- Local Leadership: Usually people who deal with local governments, especially in rural areas, are characterized by a lack of experience, professionalism. Therefore they should be provided with leadership-management skills in order to develop various projects initiated.

- Local accountability: This means that local representatives of the people are elected by them to meet the ultimate goal that is to provide services in the most effective manner possible. If this is not achieved then the vote of the people make them to not be re-elected at the next election.

- Local development: This is very important feature, because the primary goal is the development of local government within the area which exercises jurisdiction.

\section{The importance of local government}

The importance of this government is primarily in support of democracy. As if democracy is to function properly, then it is necessary the participation of as many citizens in the decision making process. Progress achieved on the basis of these methods is more solid and democratic than that achieved over the communist totalitarian methods.

As the first Indian Prime Minister Jawaharlal Nehru said in 1948 (Aijaz, 2007):

"... Self-governance is and should be the basis of any truly democratic system. You can not build a consolidated democracy, if you don't build its foundation from below ... "

Secondly, the local government can create future leaders. This means that local government is a training period and effective enough to gain experience and knowledge on the art of government policy-making and governance transition to nationwide. This has happened in our country, where yesterday's mayors have used their position as a springboard to move to the party leadership or central governments. This underlines once again that the best school of democracy and the best guarantee for success is the practice in local government.

Thirdly, its importance lies in the fact that manages much better and more efficiently the local affairs as it is closer to the needs of citizens.

Finally, its importance lies in the fact that it serves as a communication tool and an intermediary between the central government and the people or community. Thus requirements of citizens are transmitted to the central government by local government bodies and on the other hand the central government policies are made known to the public through local government organs. This two-way relationship makes possible a close relationship between people and high levels of government.

\section{CONCLUSION}

There are many definitions regarding the local governance from many authors, each of them depending on the way that has studied it. The local governance has some very important characteristics that gives its importance, such as decentralization and local autonomy, which made the function part of it.
Its importance regards the fact that it better suits the local needs, but also gives a better representation of the local peoples and their will. Also, this kind of government can serve as a trampoline for the national leadership in the future. But also it's a communication tool between the central and local authorities and people.

\section{REFERENCES}

Aijaz, R. (2007). "Challenges for urban Local Governments in India", Asia Research Centre Working Paper 19, retrieved from www.Ise.ac.uk/asiaResearchCentre/_files/ARCWP19_Aijaz.pdf on February 22

Crawford, A. (1999, October 28). "The local governance of crime: Appeals to community and partnerships"; ISBN-13: 978 0198298458

De Tocqueville, A. (1966). "Democracy in America", Published by Arlington House.

Faguet, J. P. (2005 August). "Governance from below, a theory of local government with two empiricaltests", Research paper http://sticerd.Isc.ac.uk/dps/pepp/pepp12.pdf

Godwin, M. L., \& Foremand, D. S. (2014, December 11). "Local politics and mayoral elections in 21st century America: The keys to City Hall (Routledge Research in Urban Politics and Policy), Routledge 1st edition, ISBN-13:978-1138821316.

Hampton, W. (1991, May). "Local government and urban politics" Published by: Longman group UK, 2nd edition, ISBN-13: 978 0582062047.

Hasluck, E. L. (2010). "Local government in England".

Humes, S., \& Martin, E. M. (1961). "The structure of local governments throughout the world" 1961, published by Martinus Nijhoff.

Keating, M. (1991, December). "Comparative Urban Politics: Power and the city in the United States, Canada, Britain and France", Published by: Edward Elgar Pub,ISBN-13: 978-1852781552.

Lockard, D. (1963). "The politics of state and local government", Macmillian 1st edition.

Sidgwick, H. (2014, October 22). "The elements of politics".

Stones, P. (1968). "Local government for students" published by Macdonald and Evans, 3rd edition.

Tindal, C. R. (1977). "Structural changes in local government: Government for urban regions" (Monographs on Canadian urban government).

Wilson, R. H. (2000, April 3). " Understanding local governance: An international perspective" (working paper series).

Wilson, W. \& Game, Ch. (2006, August 31). "Local government in the UK" Fourth edition, published by Palgrave Macmillian, ISBN-13: 978-1403997876. 